\title{
The quality of life perception by gender and place of residence during assessment of thrombocytopenia impact on patients' daily activities using TSIDAV vignette
}

\begin{abstract}
Introduction. The term "quality of life" has been present in the literature for a long time now. It was created in the middle of the last century in Western Europe and from the societal perspective the term initially defined the level of material life, gradually being expanded to other aspects of human life, like happiness, education, broadly defined individual freedom and health.

Aim. To analyze differences by gender and place of residence in perception of quality of life based on data from the assessment of thrombocytopenia impact on daily activities using TSIDAV vignette among Polish patients.

Material and methods. We assessed the impact of thrombocytopenia symptoms on patients' daily activities using TSIDAV vignette. We wanted to understand the reason for different perception of symptoms and why visible symptoms are perceived as worse by women in comparison to men. We analyzed the groups by age and place of residence.

Results. Within 48 collected questionnaires, 31 were provided by women and 17 by men. As many as $29 \%$ of men declared the biggest impact on daily activities due to petechiae and easy bruising. The same symptoms were assessed as having significant impact on daily activities by $68 \%$ and $65 \%$ of women respectively. The results in relation to the two symptoms were similar in terms of impact: both men and women assessed it as high impact, however in general, a lower proportion of men identified this as an issue. As many as $53 \%$ of the pre-menopausal women declared the thrombocytopenia impact on daily activities as very high. Similar results were observed in the male group. Those before retirement age assessed disease symptoms as very high in comparison to the group of older patients. No significant differences in relation to place of residence were observed. During literature research we found that depending on patients' gender, the perception of the impact of disease on patients quality of life may often differ.

Conclusions. We found out that the perception of disease symptoms impact on quality of life is different by women and men. That may be the result of different factors such as the influence of social roles determined for each sex. At the same time, the perception of the impact of thrombocytopenia symptoms on daily activity almost does not depend on age or place of residence of neither women nor men.
\end{abstract}

Keywords: quality of life, vignette, thrombocytopenia.

DOI: $10.1515 /$ pjph-2017-0005

\section{INTRODUCTION}

The term "quality of life" has been present in the literature for a long time now. It was created in the middle of the last century in Western Europe and from the societal perspective the term initially defined the level of material life, gradually being expanded to other aspects of human life, like happiness, education, broadly defined individual freedom and health. Quality of life is a wide concept, subjectively reflecting the assessment of all aspects of life and the general well-being. However the term "health related quality of life" is narrowed to the area where the focus is solely on aspects related to health. The patients' self-assessment of their quality of life is called PRO - patient reported outcomes and it can study different areas of patient life like patients preferences or the impact of symptoms on their daily life when using specific treatment.
The concept of quality of life is divided into narrow areas, related only to health, but for the purposes of this article, it is necessary to draw attention to broader concepts that go beyond this dimension and assess the level of a sense of the quality of life taking into account not only biological phenomena, but also social and cultural aspects $[1,2]$.

\section{AIM}

In our research we created a vignette to assess the impact of symptoms of thrombocytopenia on patients' daily activities. Following the analysis of main results, what we found interesting was to explore more deeply if and why there are some differences in the perception of the symptoms impact on daily activities among women and men.

\footnotetext{
${ }^{1}$ Department of Dermatology, Military Institute of Medicine, Warsaw, Poland

${ }^{2}$ Department of Applied Pharmacy, Medical University of Lublin, Poland

${ }^{3}$ Faculty of Social Sciences, Warsaw University of Life Sciences, Warsaw, Poland
} 


\section{MATERIAL AND METHODS}

We used the TSIDAV vignettes to assess the impact of thrombocytopenia symptoms on patients' daily activities $[3,4]$. In our research we analyzed information obtained from women and men. Based on the observed results, we aimed at understanding the reason for different perception of the symptoms and why those visible symptoms are perceived as worse by women in comparison to men.

We tried to understand if the reason for that might be that the disease becomes more visible and consequently, it is publicly known that the person is sick, or if it is related to the fact that women are paying more attention to the external appearance or are expected to pay more attention to their appearance [5].

In order to explain the gender differences in the perception of visible symptoms of the disease we decided to apply a model for the assessment of quality of life [6].

We also researched the literature to find similar results, as well as to compare them to our findings and to answer the question why the visible symptoms are perceived as worse [7].

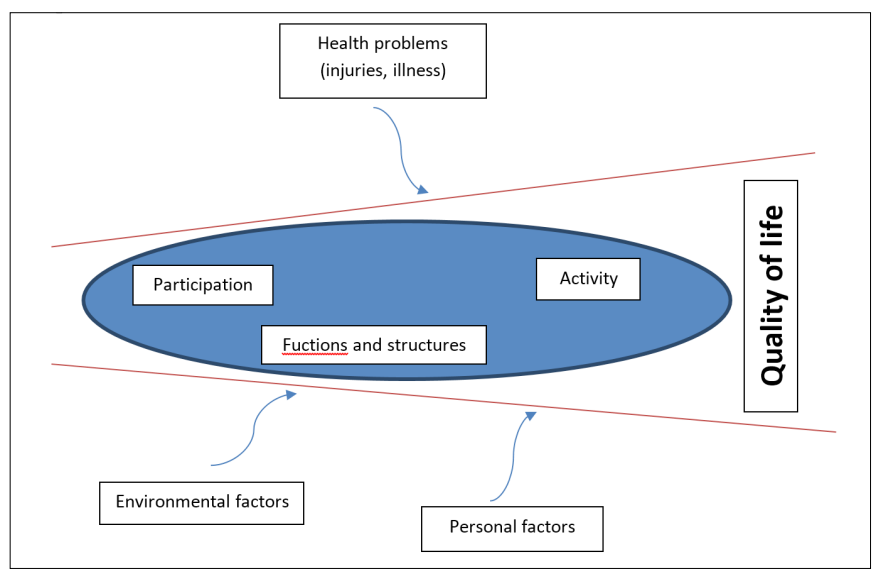

FIGURE 1. Model for QoL components.

In our model, by "personal factors" we understand the characteristics of personality having impact on the perception of people's own health using indirect complex mechanisms. These are the socio-demographic elements such as behavior, lifestyle, other diseases and past personal experiences. In the group of environmental factors in this model we included: support of loved ones, social relations, social roles attributed to gender and social perception of patients in the context of age and gender. We took into consideration the model components to better understand the results between men and women in relation to their assessment of the impact of the disease symptoms' on their daily activities.

In order to gain more understanding of the different ways the QoL perception by women, we additionally analyzed the group by age and by place of residence. We set the threshold for age as 50 years as the mean age for menopause in women in Poland [8-10]. In the analysis of quality of life in a group of pre- and post-menopausal women in Poland, it was found that the assessment of mental status was different in the analyzed groups. Also, the physical status was ranked higher in the younger group of women [10]. As far as the threshold age for men, we set it for the retirement age.

\section{RESULTS}

When analyzing the results, we found out that the same symptoms were reported as impactful by both women and men. The most significant were petechiae and easy bruising. However, we noticed that more women reported it in comparison to men.

TABLE 1. Impact of skin and mucosal petechiae on daily activities among women and men.

\begin{tabular}{cccccc}
\hline \hline & Women $(\mathrm{n}=\mathbf{3 1})$ & \multicolumn{4}{c}{ Men $(\mathrm{n}=\mathbf{1 7})$} \\
\hline Score & Number of responses & $\mathbf{\%}$ & Score & Numer of responses & $\mathbf{\%}$ \\
\hline 2 & 2 & 6 & 2 & 2 & 12 \\
\hline 1 & 1 & 3 & 1 & 3 & 18 \\
\hline 0 & 4 & 13 & 0 & 6 & 35 \\
\hline-1 & 3 & 10 & -1 & 1 & 6 \\
\hline-2 & 21 & 68 & -2 & 5 & 29 \\
\hline
\end{tabular}

TABLE 2. Impact of easy bruising on daily activities among women and men.

\begin{tabular}{cccccc}
\hline \hline & Women $(\mathbf{n = 3 1})$ & \multicolumn{4}{c}{ Men $(\mathbf{n = 1 7})$} \\
\hline Score & Number of responses & $\mathbf{\%}$ & Score & Numer of responses & $\mathbf{\%}$ \\
\hline 2 & 1 & 3 & 2 & 3 & 18 \\
\hline 1 & 2 & 6 & 1 & 3 & 18 \\
\hline 0 & 2 & 6 & 0 & 4 & 24 \\
\hline-1 & 6 & 19 & -1 & 2 & 12 \\
\hline-2 & 20 & 65 & -2 & 5 & 29 \\
\hline
\end{tabular}

The same symptoms were assessed as having significant impact on daily activities in both groups. However, the number of responses varied. Within female group the analyzed results have shown that $68 \%$ of women considered petechiae on their skin and mucosa as having a significant impact on their daily activities and as many as $65 \%$ also declared easy bruising as a significant impact on their daily life. In comparison, among men, only $29 \%$ have declared a significant impact of skin petechiae and mucosal on their daily activities and in the opinion of $12 \%$ of men there was no impact at all. As many as $29 \%$ of men considered easy bruising as a significant impact on their daily activities, while $18 \%$ did not perceive it as having any impact.

When asked to provide detailed information on what symptoms are those which most affected their daily activities, $41 \%$ of men reported weakness, fatigue and lack of strength. When we asked the same question to women, $35 \%$ of women reported weakness.

The literature research showed that often the different perception of the impact of disease on patients' quality of life depends on patients' gender, however the reason for such differences is not clear. When analyzing responses shown in table 3 by age in women, we can observe that in the older group most of the patients perceive the impact of thrombocytopenia symptoms on their daily activities as high and in the premenopausal group as many as $53 \%$ of respondents declared the impact as very high. Similar results were observed in men. As shown in table 4, the group of men before retirement assessed the disease symptoms as very high in comparison to the older group where the most frequent answer was high impact on daily activities. 
What is interesting, is that the distribution of answers within both male groups was more equalised and balanced than in women. Among younger men the ranking from low impact through no impact to high impact was similar and accounting to $20 \%$ of responses for each category. As many as $40 \%$ declarations were ranked as very high impact. In the older group the distribution of answers remained in the same categories, however $43 \%$ assessed the impact as high. Analyzing female answers, the younger group's perception of impact of the symptoms is higher in comparison to men and there are no patients declaring very low or low impact of the symptoms on their daily activities.

TABLE 1. Women, by age (assumed 50 years as the average age of menopause in Poland).

\begin{tabular}{ccccc}
\hline \hline Women & \multicolumn{2}{c}{ Below 50 years $(\mathbf{n = 1 5})$} & \multicolumn{2}{c}{ Above 50 years $(\mathbf{n}=\mathbf{1 6})$} \\
\hline Value & Number of responses & $\mathbf{\%}$ & Numer of responses & $\%$ \\
\hline $1.1-2.0$ & 0 & 0 & 0 & 0 \\
\hline$>0-1.0$ & 0 & 0 & 2 & 12.5 \\
\hline 0 & 1 & 7 & 0 & 0 \\
\hline$<0--1.0$ & 6 & 40 & 12 & 75 \\
\hline$-1.1--2.0$ & 8 & 53 & 2 & 12.5 \\
\hline
\end{tabular}

TABLE 4. Men, by age (assumed 65 years as the retirement age in Poland).

\begin{tabular}{ccccc}
\hline \hline Men & \multicolumn{2}{c}{ Below 65 years $(n=10)$} & \multicolumn{2}{c}{ Above 65 years $(n=7)$} \\
\hline Value & Number of responses & $\%$ & Numer of responses & $\%$ \\
\hline $1.1-2.0$ & 0 & 0 & 0 & 0 \\
\hline$>0-1.0$ & 2 & 20 & 2 & 29 \\
\hline 0 & 2 & 20 & 1 & 14 \\
\hline$<0--1.0$ & 2 & 20 & 3 & 43 \\
\hline$-1.1--2.0$ & 4 & 40 & 1 & 14 \\
\hline
\end{tabular}

As an additional analysis we split patients by place of residence. The results shown in table 5 provide information on how patients assessed the thrombocytopenia symptoms impact on the daily activities depending on the fact whether they live in a city or a country side.

TABLE 5. Women and men by place of residence.

\begin{tabular}{|c|c|c|c|c|c|c|c|c|}
\hline \multirow[b]{2}{*}{ Value } & \multicolumn{4}{|c|}{ Women $(n=31)$} & \multicolumn{4}{|c|}{ Men $(n=17)$} \\
\hline & $\begin{array}{l}\text { Number of women } \\
(n=17)\end{array}$ & $\%$ & $\begin{array}{c}\text { Number of men } \\
(n=6)\end{array}$ & $\%$ & $\begin{array}{l}\text { Number of women } \\
(n=14)\end{array}$ & $\%$ & $\begin{array}{c}\text { Number of men } \\
(n=11)\end{array}$ & $\%$ \\
\hline $1.1-2.0$ & 0 & 0 & 0 & 0 & 0 & 0 & 0 & 0 \\
\hline$>0-1.0$ & 1 & 6 & 1 & 17 & 1 & 7 & 3 & 27 \\
\hline 0 & 0 & 0 & 2 & 33 & 1 & 7 & 2 & 18 \\
\hline$<0--1.0$ & 10 & 59 & 1 & 17 & 8 & 57 & 4 & 36 \\
\hline$-1.1--2.0$ & 6 & 35 & 2 & 33 & 4 & 29 & 2 & 18 \\
\hline
\end{tabular}

Among men living in the countryside, as many as $36 \%$ (the highest percentage in this group) declared high impact of the symptoms on their daily activities. While $57 \%$ of women living in the countryside declared the impact as high. Patients living in a city perceived the impact as high by $59 \%$ of women, and very high by $35 \%$ of women. Among men living in a city, the distribution was different and 33\% declared no impact with the same percentage declaring very high impact on their daily activities.

\section{DISCUSSION}

The observed differences between women and men are visible in our research. Factors such as the social roles determined for each sex may be a decisive factor in an attempt to explain the differences in the perception of differences visible symptoms of the disease. Gender stereotypes are present not only in the male attitudes, but also in the female attitudes. In Polish society women impose obligations on themselves and claim features that valuable woman should have such as: perfect health or good and attractive appearance. It is necessary to stress that any imperfection of the body can influence the perceived quality of life much more than the visible symptoms of the disease. Women are afraid of losing their attractiveness, the attributes of femininity, feel afraid of being socially rejected, especially when their main activity is focused on building relationships with other people.

Similar differences between genders were observed by many researchers in different areas, for example, in case of hemodialysed patients, researchers used the KDQOL-SF to assess QoL. The scores showed statistically significant differences between men and women in four scales/areas: physical functioning, emotional role limitation, social functioning and emotional well-being. Authors also observed statistically significant gender-related differences in the following areas: educational level, employment, haemoglobin, $\mathrm{Kt} / \mathrm{V}$, trait anxiety and depressive symptoms. Authors concluded that the impaired HRQOL in hemodialyzed women reflects the gender-related differences that are also shown in the general population and they are related to the higher prevalence of trait anxiety and depressive symptoms in women [11].

In another study, patients with thrombocytopenia (ITP) completed a one-time web-based survey to assess HRQOL. The questionnaires used were as follows: SF-36, the EQ-5D, and the ITP-Patient Assessment Questionnaire (ITP-PAQ). The population answering the survey was predominantly women (76\%). As ITP can affect women differently from men the ITP-PAQ has scales related to menstrual symptoms and fertility issues for female respondents only. Authors observed that gender was a statistically significant covariate in several of the comparisons. When comparing ITP patients to control group, gender was a statistically significant covariate for all eight SF-36 scales and the EQ-5D index score. Gender was also statistically significant for three SF-36 scales (Physical Function, Vitality, Physical Component Sum-

mary) and three ITP-PAQ scales (Symptoms, Fatigue, Bother) in the comparison between splenectomized and non-splenectomized patients and also in the linear regression models exploring the relationship between platelet count and Vitality and Social Function [12].

Patients with psoriasis provided information on their quality of life in a study, where authors measured stigmatization with the Questionnaire on Experience with Skin Complaints. QoL was measured using the Dermatology Life Quality Index (DLQI) and the Short Form-8 Health Survey (SF-8). 
The researchers observed that men and women experience differently discomfort, stigmatization and mental aspects of QoL. In conclusion, the findings suggest that the effect of stigmatization on skin-related QoL is driven by symptom severity and stigmatization combined and, although women and men experience the social impact of psoriasis differently, both men and women assess the effect of stigmatization on QoL in a similar way [13].

\section{CONCLUSIONS}

We found out that the perception of disease symptoms impact is different by women and men [14]. That may be the result of different factors, such as the influence of social roles determined for each sex. At the same time, the perception of the symptoms of thrombocytopenia impact on daily activity almost does not depend on age nor place of residence of both women and men.

\section{REFERENCES}

1. Telka E. Ocena jakości życia w wymiarze psychologicznym, zdrowotnym i społecznym. Nowa Med. 4/2013.

2. Cieślik A, Słopiecka A. Quality of life in the social sciences. Stud Med. $18 / 2010$.

3. Drozd M, Szkultecka-Dębek M, Bem M, et al. Thrombocytopenia Symptoms and their Impact on Patients Daily Activities assessment Vignette (TSIDAV) - validation of the vignette. JHPOR. 2016;1. [http://www.jhpor. com/index/artykul/pokaz/thrombocytopenia_symptoms_ and_their_impact_on_patients_daily_activities_assessment_vignette_tsidav_validation_of_the_vignette]

4. Szkultecka-Debek M, Drozd M, Nowakowska M, et al. The assessment of the impact of thrombocytopenia symptoms on the patients' daily activities with the use of TSIDAV vignette. JHPOR. 2016;1. [http://www.jhpor.com/ index/artykul/pokaz/the_assessment_of_the_impact_of_thrombocytopenia_symptoms_on_the_patients_daily_activities_with_the_use_of_tsidav_vignette]

5. Kotlarska-Michalska A. Społeczne role kobiet. Edu Human. 2011;1(24).

6. Santé publique, qualité de vie et maladies chroniques, Direction Générale de la Santé: Actes du séminaire préparatoire au plan visant à améliorer la qualité de vie des personnes atteintes de maladies chroniques. Paris ; 2004.

7. Owisiński JW, Tarchalski T. Pomiar jakości życia. Uwagi na marginesie pewnego ranking. Współcz Probl Zarządz. 2008;1.

8. Pertyński T. Menopauzalny okres życia kobiety. Przew Lek. 2002;5(1/2):69-71. [http://www.termedia.pl/Czasopismo/Przewodnik_Lekarza-8/Streszczenie-701.]

9. Przekwitanie. Klinika Endokrynologii Ginekologicznej. Warszawski Uniwersytet Medyczny. [https://endogin.wum.edu.pl/sites/endogin.wum.edu. $\mathrm{pl} /$ files/okres_przekwitania_u_kobiet.pdf.]

10. Szkup-Jabłońska M, Tutaj E, Jurczak A, et al. Wpływ warunków socjodemograficznych na jakość życia kobiet $w$ okresie pomenopauzalnym. Perinatol Neonatol Ginekol. 2012;5(1):34-38. [http://www.ptmp.com.pl/png/ png5z1_2012/PNG51-6-Szkup.pdf.]

11. Vázquez I, Valderrábano F, Fort I, et al. Differences in health-related quality of life between male and female hemodialysis patients. Nefrol. 2004;24(2):167-78

12. Snyder CF, Mathias SD, Cella D, et al. Health-related quality of life of immune thrombocytopenic purpura patients: results from a web-based survey. Curr Med Res Opin. 2008;24(10):2767-76.

13. Böhm D, Stock Gissendanner S, Bangemann K, et al. Perceived relationships between severity of psoriasis symptoms, gender, stigmatization and quality of life. J Eur Acad Dermatol Venereol. 2013;27(2):220-6.

14. Paruzel-Czachura M. Poczucie jakości życia i poziomu wyczerpania witalnego u aktywnych zawodowo kobiet i mężczyzn. Studia Psychologica UKSW. 2013;13(1).

Corresponding author

Monika Szkultecka-Dębek

Department of Dermatology, Military Institute of Medicine, Warsaw

128 Szaserów St., 04-141 Warszawa

E-mail: monikasz.debek@gmail.com 